\title{
Measuring 'Sustainable' Innovation in Greece: A Patent Based Analysis
}

\author{
Maria Markatou
}

National and Kapodistrian University of Athens, Technological Education Institute of Larissa, Greece

\begin{abstract}
This paper is the first attempt to measure 'sustainable' innovation in Greece. 'Sustainable' innovation is a critical dimension of sustainable development and a process where sustainability considerations, such as environmental, social, financial, are integrated into the generation of new ideas, leading to new R\&D and to new commercialisation. This applies to products, services and technologies, as well as new business and organisation models. This paper focuses on the environmental considerations of 'sustainable' innovation, namely innovation that aims at reducing impacts on the environment, achieving a more efficient and responsible use of natural resources, saving energy, promoting ecological building, contributing to sustainable agriculture, etc.
\end{abstract}

Patent data has been used for the measurement of 'sustainable' innovation in Greece. The analysis shows that Greek innovation follows the existing industrial pattern, which is characterized by its traditional orientation. The majority of new technologies and probable innovations are related to chemicals, the construction industry and the agricultural sector. Almost the $15 \%$ of patents could be directly linked to 'sustainable' innovation, focusing on the optimization of the exploitation of natural resources. On the contrary we have no patents in 'sustainable' agriculture. Deepening our analysis it can be shown that Greek inventors develop patents aiming at the saving of energy in buildings. Greece faces very severe structural and fiscal problems, while is now discussing its new development agenda. This paper could contribute to this discussion, particularly to this part of policy which is related to environmental issues and related measures.

Keywords: Eco-innovation, Greece, Patents, Sustainability.

\section{Introduction}

The debate on sustainable development emerged in the 1980s and was reinforced since the 1990s by several national and international initiatives. Sustainable development is the development that satisfies the needs of today without risking the capacity of the future generations to satisfy their own needs. The role of innovation in this procedure is central. Innovation can be defined as the successful exploitation and commercialisation of new ideas. Integrating the concepts of innovation and sustainable development, the existing bibliography introduced the term 'sustainable' innovation and defined it as the process of developing new products, processes or services which on the one hand provide customer and business value but on the other hand significantly decrease environmental impact and face the challenges of climate change.

Empirical research measures 'sustainable' innovation applying the same methodology and exploiting the same methods of analysis that it uses for the study of innovation in general (Archibugi and Pianta 1996, Grupp 1998 and Smith 2005), namely constructing indicators based on the four following kinds of measures: First, input measures (e.g. indicators based on $\mathrm{R} \& \mathrm{D}$ expenditures and personnel,

Copyright (C) 2012 Maria Markatou. This is an open access article distributed under the Creative Commons Attribution License unported 3.0, which permits unrestricted use, distribution, and reproduction in any medium, provided that original work is properly cited. Contact author: Maria Markatou E-mail: markatou@prd.uth.gr 
innovation expenditures); Second, intermediate output measures (e.g. indicators based on patents, scientific publications); Third, direct output measures (e.g. number of innovations, descriptions of individual innovations, data on sales of new products); Four, indirect impact measures (e.g. indicators based on aggregate data, changes in resource efficiency and productivity using decomposition analysis). Empirical research also obtains data mainly from two sources: First, data based on the existing sources of statistical agencies (e.g. European Patent Office) and second data based on specially designed surveys (e.g. CIS innovation surveys).

This paper studies the environmental considerations of 'sustainability' measuring 'sustainable' innovation through patent data. This analysis is the first research effort to study and measure 'sustainable' innovation in Greece. The results could be very useful for Greece, as the Greek government has started discussing the implementation of a new development policy with the environmental issues being central to this policy. The paper, however, could also contribute to the existing body of knowledge and practice, as it examines the case of a country with very important environmental advantages, where the promotion of 'sustainable' innovation could make the difference, being a paradigm and a 'strong' national case. In this context this paper describes and measures 'sustainable' innovation in Greece and examines whether the Greek pattern is close or far away to the new emerging environmental challenges and the targets of 'sustainable' development.

The rest of this paper is structured as follows: Section two presents a bibliography review on 'sustainable innovation' in relation to patent data. Section three deals with some methodological issues and describes data. Section four analyzes the overall pattern, focusing on the main facts and trends. Section five synthesizes and further discusses the results. Finally section six presents some concluding remarks.

\section{Bibliography Review}

Empirical research has extensively used patents for the measurement of innovation, taking advantage of their important advantages. However, empirical research has also highlighted their limitations when used in economic analysis. In relation to their advantages, patents are linked to and can measure both inventions and innovations. As a measure of inventions patents have a close (if not perfect) link to inventions (OECD 2009). Patents cover a broad range of techniques, extending now to biotechnology and software, with first extensions towards services-related inventions (so-called "business methods") (OECD 2005). Patents enable researchers to study and to assess different features of innovative processes. On the basis of the huge literature on patents, we can highlight some major research directions that have been examined through patents, such as the level of inventive activity, studied by Griliches (1990), Lanjouw and Mody (1996), Cohen et al. (2000) and Popp (2005). Another research direction is the study of the different types of innovation and technological competencies of organizations investigated by many economists and among them we could mention the research study of Breschi et al. (2003). Others, such as Marinova and McAleer (2003) focused on the technology strengths of nations, while one of the most ambitious research fields is perhaps the field that examines the emerging patterns of technology diffusion, knowledge relatedness and spillovers, mainly explored by Scherer (1982), Jaffe (1986 and 1989), Engelsman and Van Raan (1994) and Verspagen (2005).

However, patents also present strong weaknesses. Patents do not capture all innovations, but a restricted part of it. As a matter of fact, as Levin et al. (1987) first mentioned, some innovations are not patentable and, even when they are, patents are not considered by firms to be the most efficient way of protecting and of appropriating innovations (Crepon et al. 2000). 
Moreover, firms are more likely to patent research that results in new products, rather than research that results in new processes. This means that patent data correspond to a biased sample of innovations since they only concern technological innovations and tend to overestimate product innovations, a disadvantage that was clearly argued by Popp (2005). In addition surveys on patenting firms also indicate that the rate at which new innovations are patented varies across industries, countries and patent offices, meaning that the propensity to patent differs. These significant differences, as Pavitt (1984) and Malerba and Orsenigo (1996) mention, are linked to both the types of innovations and the characteristics of technological regimes in terms of knowledge bases, cumulativeness of innovation and technological opportunities. The last weakness concerning patents is the issue of their value. The value of a patent depends on its contribution to the economy, in technological or in economic terms. Defining this way there are patents of high value and those of very low value. However, patent offices don't discriminate among them and we usually treat them equally, which could be a problem, as Guellec and van de la Potterie argue (2000).

Focusing on 'sustainable' innovation, the existing bibliography directly relates the above term with the issue of environment. So, empirical research has so far focused on studying and measuring environmental innovation. The part of empirical research which analyses 'sustainable' innovation using patent data is large. For example Lanjouw and Mody (1996) counted the number of patents in nine environmental fields (including alternative energy) and studied the issue of diffusion of environmental technologies. They used international patent data to track patterns of diffusion. Popp (2006) also used patent citations to study environmental innovation, while later on he studied the pollution control technologies. The level of eco-innovation activities, the directions of research in certain environmental fields and their historical evolution was studied by both Frenken et al. (2004) and Oltra and Saint Jean (2009). These researchers also dealt with the competencies of organizations in environmental technologies focusing on the field of low emission vehicles (LEVs). Nameroff et al. (2004) studied green chemistry patents based on US patents. Their research ended up with the identification of 3235 green chemistry US patents. Johnstone et al (2008) focused on renewable energy patents. Finally, Marinova and McAleer (2006) studied the environmental technology strength of nations with the use of patent data, finding that Germany is the best performing country in a group of 12 countries, and Canada and Japan ranked equal second. Lee et al. (2009) presented data on six energy technologies using a 'patent landscaping' technique: wind, solar photovoltaic (PV), concentrated solar power (CSP), biomass-electricity, carbon capture and cleaner coal.3.

Summarizing, the number of studies that have used patents in empirical research is very large. The measurement of 'sustainable' innovation through patents is a very promising field. The previous bibliography review showed that we can study and measure 'sustainable' innovation using patents if we always take into consideration their limitations and disadvantages.

\section{Methodology: Our Data and Their Elaboration}

This paper aims at measuring 'sustainable' innovation in Greece based on patent data. This means that our main data source is a national or international patent office and our main unit of analysis is the patent document. Working with patents implies first choices and then decisions on methodology and elaboration of data. In our case four methodological choices were made, which led to respective decisions. The first three concern the construction of the patent database and its elaboration while the forth refers to the definition and description of the term 'sustainable' innovation. In relation to the patent database we decided to: (1) collect only patent documents from the Greek patent 
office and start from its establishment (1988), as we wanted to study the national pattern in total and in time; (2) work with patent grants instead of simple applications, as we wanted to give some quality to our data and (3) focus on Greek firm patents instead of examining all patents, namely patents owned by foreigners, individuals or other nonprivate owners, as the aim of this paper is the measurement of 'sustainable' innovation in Greece and firm patents are more likely to become innovations than patents from other types of inventors. Therefore, this paper exploits first an initial patent database, which contains all patents that were granted in Greece during the period 1988-2005 (5033 foreign and Greek patents in total). Based on this data we then constructed and elaborated a second patent database, which contains 729 firm patents in total, all owned by Greek firms.

Both databases contain the same information fields:

(1) number of patent, (2) number of application, (3) international technology classification (IPC), (4) name of beneficiary, (5) date of application, (6) date of patent granting, (7) conventional priorities, (8) amendments to the main patent, (9) name of inventor, (10) data of inventor, (11) special surrogate attorney, (12) name of invention and (13) brief summary of patent content. The third information field, that is the international technology classification, was further disaggregated into 5 technology sub-fields (sector, sub-sector, class- subclass and main group) for each patent code that the patent has been classified to. This means that the 729 firm patents are corresponded to 729 first IPC codes (first code) and 1490 'total' patent codes (all codes). The examination of all IPC codes adds to our analysis more detail and reliability, as we describe this way first the complete technological content of each patent, second all possible technological directions and economic uses and, third, all interconnections between different technologies.

The fourth methodological choice concerned the definition of both 'sustainable' innovation and its relevant fields. In relation to the former we define 'sustainable' innovation an innovation that first ends up on a new or improved environmental technology (e.g. pollution control technologies and green energy technologies, and for general purpose technologies with environmental benefits), second a related production or service innovation, and, third, the introduction of an new business method or organizational measure, or a 'green' system innovation. However, we do acknowledge that new business methods and organisational innovations can almost be never patented (OECD 2008). Therefore our analysis focuses on the new to the world patented technological innovations and more precisely on product innovations that can be described by related patent data. In relation to the latter (definition of 'sustainable' fields) the existing bibliography shows that researchers construct 'sustainable' fields based on relevant 'sustainable' keywords. We also constructed 'sustainable' keywords. In fact we have introduced the following 'sustainable' fields: (1) renewable energy and resources or alternative energy (solar, hydro, wind, geothermic energy and resources); (2) technologies related to vehicles (e.g.. electrical and hybrid vehicles); (3) energy technologies related to house- domestic, commercial and industrial sectors (e.g. insulation, heating, lighting, cement industry); (4) recycling (e.g. reusing waste); (5) elaboration of waste and their disposal (e.g. radioactive, solid, waste water, incineration of waste), (6) technologies related to pollution (e.g. air, industrial, vehicle, water cleaning technologies), (7) technologies that protect from the noise; (8) cultivations and general activities of the agricultural sector and (10) rest technologies in relation to sustainable development, such as monitoring equipment and other applications.

Empirical research in this field uses two kinds of methods for the measurement of 'sustainable' innovation: The first method is based on the examination of all codes classified to each patent according to the international technology classification (IPC) and in relation to 'sustainable' 
matters. Thus, the first method focuses on the technological content of each patent as derived from its assignment to one or more patent codes and its interpretation. The second method relies on the 'creation' of keywords which should be also closely related to 'sustainable' matters. Thus, the second method scans every patent in a dual way, both its short description and the interpretation of the technological content of each patent searching for these keywords. This paper measures 'sustainable' innovation in Greece using both kinds of methods: It starts by examining all IPC codes assigned to each patent (one or more patent codes), then 'reads' both the interpretation of these codes and the short description of every patent and finally classifies each patent to a 'sustainable' field based on the above 'sustainable' fields.

\section{Main Findings and Results}

The general technology pattern shows that the technology 'medical or veterinary science- hygiene' is the most important class. Greek patents are more related to 'agriculture, forestry, animal husbandry, hunting, trapping- fishing' (e.g. planting; sowing; fertilising; harvesting; mowing; animal husbandry) and 'building' (e.g. general building constructions; finishing works on buildings). Focusing on the sample of patents owned by Greek firms and based on the international patent classification we can see in the table that follows (table 1) the most important technologies according to their percentage shares. Greek firms develop patents, which are related to different in nature technologies, such as first technologies of 'building' (e.g. walls, partitions, roofs or insulation, doors, windows, locks, accessories handcuffs, stairs), second 'medical or veterinary science; hygiene' (e.g. preparations for medical, dental or toilet purposes), third 'conveying; packing; storing; handling' (e.g. containers for storage or transport or articles or materials), four 'shaping' (e.g. working or processing of sheet metal or metal tubes, rods or profiles without essentially removing material; punching), five 'appliances and apparatus' (e.g. displaying; advertising; signs; labels or name- plates, seals) and six 'electricity' (e.g. electricallyconductive connections; Structural associations or a plurality of mutually insulated electrical connecting elements; coupling devices; current collectors). 
Table 1: The Most Important Technologies of the Patents Owned by Greek Firms- IPC: Sub-Classes, Shares and Related Manufacturing Branch

\begin{tabular}{|c|c|}
\hline IPC- subclasses ${ }^{1}$ & Manufacturing branch 3 \\
\hline $\begin{array}{l}\text { Preparations for medical, dental or toilet } \\
\text { purposes }\left(8.39 \%^{2}\right)\end{array}$ & $\begin{array}{l}\text { Pharmaceutical preparations } \\
\text { Household and sanitary goods and of toilet } \\
\text { requisites }\end{array}$ \\
\hline $\begin{array}{l}\text { Horticulture; cultivations; forestry; watering } \\
(3.62 \%)\end{array}$ & Agricultural and forestry machinery \\
\hline $\begin{array}{l}\text { Fixed or movable closures for openings in } \\
\text { buildings, vehicles, fences or like enclosures in } \\
\text { general ( } 3.29 \%) \\
\text { General building constructions; Walls (e.g. } \\
\text { partitions, roofs, floors, ceilings, insulation or } \\
\text { other protection of buildings }(1.88 \%)\end{array}$ & $\begin{array}{l}\text { Basic metals- Fabricated metal products } \\
\text { Aluminium production, } \\
\text { Builders' carpentry and joinery of metal, } \\
\text { Locks and hinges, } \\
\text { Metal structures and parts of structures }\end{array}$ \\
\hline $\begin{array}{l}\text { Containers for storage or transport or articles } \\
\text { or materials; accessories, closures or fittings } \\
\text { therefore; packaging elements; packages } \\
(3.09 \%) \\
\text { Pipes; Joints or fittings for pipes; supports for } \\
\text { pipes, cables or protective tubing; means for } \\
\text { thermal insulation in general (1.74\%) }\end{array}$ & $\begin{array}{l}\text { Rubber and plastic products (plastic } \\
\text { products, plates, sheets, tubes and profiles) }\end{array}$ \\
\hline $\begin{array}{l}\text { Displaying; advertising; signs; labels or name- } \\
\text { plates, seals }(2.48 \%)\end{array}$ & Optical instruments \\
\hline $\begin{array}{l}\text { Foods, foodstuffs or non- alcoholic beverages, } \\
\text { not covered elsewhere, their preparation or } \\
\text { treatment }(2.35 \%)\end{array}$ & $\begin{array}{l}\text { Production of meat and poultry meat } \\
\text { products, } \\
\text { Bread; manufacture of fresh pastry goods } \\
\text { and cakes, } \\
\text { Foods or foodstuffs and their treatment }\end{array}$ \\
\hline $\begin{array}{l}\text { Functional features or details of lighting devices } \\
\text { or systems thereof; Structural combinations of } \\
\text { lighting devices with other articles, not } \\
\text { otherwise provided for }(2.01 \%)\end{array}$ & Lighting equipment and electric lamps \\
\hline Elevators, escalators, or moving & $\begin{array}{l}\text { No specific purpose machinery (lifting and } \\
\text { handling equipment) }\end{array}$ \\
\hline $\begin{array}{l}\text { Electric digital data processing, } \\
\text { Electrically- conductive connections; Structural } \\
\text { associations or a plurality of mutually insulated } \\
\text { electrical connecting elements; coupling } \\
\text { devices; current collectors (1.48\%) }\end{array}$ & $\begin{array}{l}\text { Office machinery and computers } \\
\text { Electric distribution, control, wire, cable }\end{array}$ \\
\hline \multicolumn{2}{|c|}{$\begin{array}{l}1 \text { Technological sub- classes based on the International Patent Classification (Edition 11). } \\
2 \text { Percentage share of each subclass in the total technological taxonomy of the sample of patents } \\
\text { owned by Greek firms taking into consideration all patent codes assigned to each patent. } \\
3 \text { Manufacturing branch of the sub-class based on its technological content and on its } \\
\text { interpretation on economic terms. }\end{array}$} \\
\hline
\end{tabular}

Trying to interpret these new technologies and possible innovations in economic terms we can see that the technologies of 'building' are related to basic metals and fabricated metal products, such as the production of aluminium and the manufacture of metal structures and parts of structures, builders' carpentry and joinery of metal, and locks and hinges. The preparations for medical, dental or toilet purposes are obviously directed to the manufacture of chemical and chemical products and more precisely to pharmaceutical preparations, household 
and sanitary goods and toilet requisites. The technologies in horticulture, cultivations forestry and watering, such as vegetables, flowers, rice, fruit, vines, hops or seaweed are closely related to the agricultural sector, but based on the interpretation of the respective patent codes, they lead to machinery and more specific to agricultural and forestry machinery. The technologies foods, foodstuffs or non- alcoholic beverages, their preparation or treatment, such as cooking, modification of nutritive qualities, physical treatment, and preservation of foods or foodstuffs are directly directed to the branch of food and beverages, which can further specialized to the production of meat, poultry meat products, bread and related products. The containers for storage or transport, such as bags, barrels, bottles, boxes, cans, cartons, crates, drums, jars, tanks, hoppers, forwarding containers are economically related to the production of rubber and plastic products. The technologies of displaying, advertising, signs, labels or name- plates and seals can be linked to the manufacture of optical instruments. Finally all technologies classified to the group electricity are characterized by a clearer pattern: they are directly related to the manufacturing sector of electric distribution, control, wire and cable.

Based on the above general pattern, our analysis shows that there is no presence of 'sustainable' technologies and innovations. However our more detailed elaboration of both patent codes and keywords shows different things. We managed to record 13 different kinds- categories of 'sustainable innovation': (1) air energy, (2) solar energy, (3) geothermic energy, (4) energy related to sea waves, (5) hydro energy, (6), energy from biomass, (7) energy from waste, (8) electrical and hybrid vehicles, (9) insulation, (10) heating, (11) lighting, (12) cement industry and (13) waste that has been processed biologically. From this classification the first seven kindscategories belong to the field 'renewable energy and resources', where we have a total of 48 patent codes mainly in the category of solar energy and its exploitation, energy from sea waves and energy from waste. On the contrary the representation of technologies related to hydro and air energy is almost zero. At the same time there are only two patents classified in the field 'electrical and hybrid vehicles'. In general, almost the $50 \%$ of the total patents related to 'sustainable innovation' is directed to technologies that aim at the more efficient energy use and exploitation of energy in the housedomestic, commercial and industrial users, where the majority of patents concerns the insulation in buildings and more general in the construction sector. On the contrary very few patents are related to heating, none with lighting and only six to the waste that has been processed biologically. Concluding only the $15 \%$ of the patents by Greek firms could be defined as 'sustainable' innovations.

\section{Discussion and Synthesis of our Results}

In this paper we attempted to measure 'sustainable' innovation in Greece through patent data. Patent data can be used for this purpose by searching for 'sustainable' relevant patents. 'Sustainable' innovation can be defined as the creation of novel and competitively priced goods, processes, systems, services, and procedures that can satisfy human needs and bring quality of life to all people with a life-cycle-wide minimal use of natural resources (material including energy carriers, and surface area) per unit output, and a minimal release of toxic substances.

The analysis shows that 'sustainable' innovation isn't still important in Greece in quantitative terms. The production of innovation seems to follow a more traditional pattern, closely related to the existing production structure. Innovations in first the construction sector, second pharmaceuticals and related products, third food and beverages, fourth machinery and fifth the agricultural sector highlight the main technological portrait. As for the quantity and the content of 'sustainable' innovation our examination shows that the majority of them are related to renewable energy sources aiming at the optimization of the use and exploitation of natural resources. On the contrary there are no 
'sustainable' innovations classified at the agricultural sector. At the same time it is evident that the Greek owners develop technologies in the field of ecological or green building and generally the saving of energy in buildings. We have, therefore, another sign and a clear link between the existing production patterns and the new technology, where the sector of constructions plays a very important role.

So, innovations in the field of renewable energy sources directly or indirectly are the main focus of interest of Greek inventors. Does this pattern coincide with the existing international pattern? As we can see from the respective 'sustainable' patents statistics nearly the $80 \%$ of applications come from Japan, the US, Germany, Korea and France. Approximately one-third comes from Japan, the biggest inventor country. The existing international pattern shows that the different countries specialize in different 'sustainable' innovations. For instance in the solar energy, While Japan, Korea and the US are dominant in solar PV, Germany and France have played a leading role in solar thermal. Most of the smaller countries have also been more active in solar thermal (e.g. Israel, Spain, and Netherlands). Denmark focuses more on wind power technologies and Norway in hydro/marine technologies. However, a number of 'emerging' economies are becoming increasingly active (e.g. China, India and South Africa). Geothermal is the least concentrated technology field, with just over $60 \%$ of patent applications invented by the above five inventors, and $20 \%$ by the top inventor country, that is Japan (a similar percentage to biofuels) (OECD 2010).

At the same time and according to the shares of specialization of inventor countries in 'sustainable' fields, Greece mainly specializes in solar energy, both thermal and PV, and in hydro/ marine innovations. This means that first the external patent pattern is similar to the internal and, second, the country's performance moves to the right direction, but with very low absolute numbers (OECD 2010). In addition the Greek pattern is similar to the respective of other countries that are characterized by nearly the same natural environment and/or geographical position and/or development level (e.g. Italy, Portugal and Spain).

\section{Conclusions}

This paper is a first attempt to measure 'sustainable' innovation in Greece. Relying on patent data, following a twofold methodology, based on both IPC codes and relevant keywords, and taking into consideration that first the use of patents could raise strong methodological issues and second our findings depend on what and how we defined the term 'sustainable', we present the Greek case. The analysis shows that Greek innovation is characterized by a traditional technology orientation as a result of the existing industrial structure, where a large part of technologies is related to the construction industry and the agricultural sector. Almost $15 \%$ of patents are related to 'sustainable' innovation and particularly to the optimization of the exploitation of natural resources (renewable resources) and saving energy in buildings. We have therefore another sign that technology and production move in parallel, with the construction industry playing a very important role.

If this is a sign and a domain of possible dynamism then we need to further specialize and develop competences. This prerequisites a deeper analysis and naturally more updated data. However, we have a first indication of the direction of 'sustainable' innovation, towards saving energy in buildings and renewable resources. The former builds on the existing industrial structure expanding and advancing its potential, while the latter exploits the large national environmental advantages. International figures show that Greece performs much better in solar PV and onshore wind technologies, while based on the renewable energy country attractiveness the country is $21^{\text {st }}$ among 40 countries. The investment in renewable resources could help Greece reduce its energy import dependency while also contributing to environmental goals. The 
potential for wind is also quite high. As Greece now faces very severe fiscal and structural problems and the discussion on planning and implementing a new development policy has already started, there are many voices that insist that the investment in these technologies could be the only solution. This study is designed to contribute to this discussion.

\section{References}

Archibugi, D. \& Pianta, M. (1996). "Measuring Tchnological Change through Patents and Innovation Surveys," Technovation, 16 (9), 451-468.

Breschi, S., Lissoni, F. \& Malerla, F. (2003). "Knowledge-Relatedness in Firm Technological Diversification," Research Policy, 32 (1), 69-87.

Cohen, W. M., Nelson, R. R. \& Walsh, J. P. (2000). "Protecting Their Intellectual Assets: Appropriability Conditions and Why US Manufacturing Firms Patent (or Not)," Working Paper N. 7552, National Bureau of Economic Research, USA.

Crépon, B., Mairesse, J. \& Duguet, E. (2000). "Mesurer Le Rendement De L'innovation," Economie Et Statistique, 334 (1), 65-78 (In French).

Engelsman, E. C. \& Van Raan, A. F. J. (1994). "A Patent-Based Cartography of Technology," Research Policy, 23 (1), 1-26.

Frenken, K., Hekkert, M. \& Godfroij, P. (2004). "R\&D Portfolios in Environmentally Friendly Automotive Propulsion: Variety, Competition and Policy Implications," Technological Forecasting and Social Change, 71 (5), 485-507.

Griliches, Z. (1990). "Patent Statistics as Economic Indicators: A Survey," Journal of Economic Literature, 28 (4), 1661-1707.

Grupp, H. (1998). Foundations of the Economics of Innovation: Theory, Measurement, and Practice, Edward Elgar, Cheltenham.
Guellec, D. \& Van Pottelsberghe De La Potterie, B. (2000). "Applications, Grants and the Value of a Patent," Economics Letters, 69, 109-114.

Jaffe, A. B. (1986). "Technological Opportunity and Spillovers of R\&D: Evidence from Firms' Patents, Profits and Market Value," American Economic Review, 76 (5), 984-1001.

Jaffe, A. B. (1989). "Characterising the Technological Position of Firms with Application to Quantifying Technological Opportunity and Research Spillovers," Research Policy, 18 (2), 87-97.

Johnstone, N., Hascic, I. \& Popp, D. (2008). "Renewable Energy Policies and Technological Innovation: Evidence Based on Patent Counts," Working Paper N. 13760, National Bureau of Economic Research, USA.

Lanjouw, J. O. \& Mody, A. (1996). "Innovation and the International Diffusion of Environmentally Responsive Technology," Research Policy, 25 (4), 549571.

Lee, B., Iliev, I. \& Preston, F. (2009). 'Who Owns Our Low Carbon Future?, Intellectual Property and Energy Technologies,' Chatham House Report.

Levin, R. C., Klevorick, A. K., Nelson, R. R. \& Winter, S. G. (1987). "Appropriating the Returns from Industrial Research and Development," Brookings Papers on Economic Activity, 18 (3), 783-820.

Malerba, F. \& Orsenigo, L. (1996). "The Dynamics and Evolution of Industries," Industrial and Corporate Change, 5 (1), 5187.

Marinova, D. \& Mc Aleer, M. (2003). "Modelling Trends and Volatility in Ecological Patents in the USA," Environmental Modelling and Software, 18 (2), 195-203. 
Marinova, D. \& Mc Aleer, M. (2006). "AntiPollution Technology Strengths Indicators: International Rankings," Environmental Modelling \& Software, 21 (9), 1257-1263.

Nameroff, T. J., Garant, R. J. \& Albert, M. B. (2004). "Adoption of Green Chemistry: An Analysis Based on US Patents," Research Policy, 33 (6-7), 959-974.

OBI. (1989-2005). Industrial Property Bulletins, Greek Industrial Property Organization, Athens.

OECD. (2004). Patents and Innovation: Trends and Policy Challenges, OECD, Paris.

OECD. (2005). Oslo Manual Guidelines for Collecting and Interpreting Innovation Data, OECD, Paris.

OECD. (2008). Environmental Policy, Technological Innovation and Patents, OECD, Paris.

OECD. (2009). Patent Statistics Manual, OECD, Paris.

OECD. (2010). Climate Policy and Technological Innovation and Transfer, OECD, Paris.

Oltra, V. \& Saint Jean, M. (2009). "Sectoral Systems of Environmental Innovation: An Application to the French Automotive Industry," Technological Forecasting and Social Change, 76 (4), 567-583.

Pavitt, K. (1984). "Sectoral Patterns of Technological Change. Towards a Taxonomy and a Theory," Research Policy, 13 (6), 343-373.

Popp, D. (2006). "International Innovation and Diffusion of Air Pollution Control Technologies: The Effects of NOX and SO2 Regulation in the U.S., Japan and Germany," Journal of Environmental Economics and Management, 51 (1), 46-71.

Scherer, F. M. (1982). "Inter-industry Technology Flows in the United States," Research Policy, 11 (4), 227-245.
Smith, K. (2005). Measuring Innovation, the Oxford Handbook of Innovation, Fagerberg, J. Et Al. (Ed), Oxford University Press, Oxford.

Sun, Y., Lu, Y., Wang, T., Ma, H. \& He, G. (2008). "Pattern of Patent-Based Environmental Technology Innovation in China," Technological Forecasting and Social Change, 75 (7), 1032-1042.

Verspagen, B. (2005). "Mapping Technological Trajectories as Patent Citation Networks: A Study on the History of Fuel Cell Research," Working Paper N. 2005-020, UNI-MERIT, Holland. 